\title{
RESEARCH
}

\section{Does Loan Size Matter for Productive Application? Evidence from Nepalese Micro-finance Institutions \\ Bharat Ram Dhungana}

\section{ABSTRACT}

\section{KEY WORDS}

Entrepreneurship Skills

Loan size

Micro-finance Institutions

Productive Application
This paper examines the loan size and its productive application after involvement in micro-finance programme in western development region of Nepal. The paper is based on primary sources of data collected through structured questionnaires. The survey includes 500 clients from four districts of western development region both from government and Private microfinance institutions. The study shows that there is positive association between size of savings and loans, size of savings and loan application, current loan size and ethnicity, loan size and duration of membership, and finally loan size and its application. It has been found that clients who have taken small size of loans, they have mostly spent their loans on domestic purposes and found poor application of loans in micro-business whereas big loan size clients have greater application of loans in productive sectors. Micro-finance institutions should increase loan size (as per the provision of monitory policy) with necessary entrepreneurship skills that will help to enhance productive application of loans however, strict monitoring and supervision is essential. Thus, MFIs should give equal priority for non-financial services such as financial literacy and provision of entrepreneurship skills through government and non-government organizations that ultimately helps to utilize micro-credit into productive sectors.

MICRO-FINANCE (MF) IS A TOOL of financial inclusion and way of reaching to the poor people through group based lending system. It refers to the provision of small-scale financial services mainly to the poor and marginalized people, enabling them to raise their income level and improve living standards. The range of financial services under MF includes micro level loans, savings, insurance, transfer payments or remittances, pensions, and so on. MF services around the world are popular to the people who have no capacity for collateral against the loans but have indigenous skills and strong desire to carry out economic activities for self-employment and income generation.

MF has developed steadily and rapidly over the last 20 years. Its antecedents include co-operative and community endeavors in the $19^{\text {th }}$ century in Germany 
and elsewhere in Europe. Micro-finance emerged in the 1970s as social innovators began to offer financial services to the working poor those who were previously considered 'un-bankable' because of their lack of collateral. Once given the opportunity, not only did clients of MFIs expand their businesses and increase their incomes, but their high repayment rates demonstrated that the poor are capable of transforming their own lives, given the chance. This model of lending disproved all conventional thinking about banking (Matthaus-Maier and Von Pischke, 2009).

The rapid development of formal micro-finance started in Bangladesh in the 1970s. It was initiated by Professor Muhammad Yunus, an economist of Bangladesh who was conscious of hardship the poor faced, especially the women, in his country. Professor Yunus began the practice of microlending by giving out collateral-free loans (USD 27) from his own pocket to 42 women villagers in Jobra who were involved in income generating activities such as weaving bamboo stools and making pots. This later became the Grameen Bank which now serves more than seven million clients and is a model for many all over the world. Prof. Yunus believed that, given the chance, the poor will repay the money, and hence micro-credit has become a viable business model around the world (Mokhtar, 2011).

MF involves innovative techniques (group lending system, joint liabilities, and no need of physical collateral) to provide financial services for the certain category of people (the poor who have no access of formal financial services) with a certain purpose (principally for investment in business or productive sectors) and aimed to achieve a certain objectives (poverty reduction and financial inclusion). It is a unique among development intervention that facilitates to transform the socioeconomic status of the people through microcredit services. The formal financial institutions like commercial banks became failure to provide loans to the marginalized people without collateral. Micro-finance institutions (MFIs) deliver both financial and non-financial services to the clients.

Salia and Mbwambo (2014) examine the effect of micro-credit on borrowers' businesses of women owned micro-enterprises in Tanzania. This study was made with 217 borrowers and 183 nonborrowers in three major cities in Tanzania. The study shows that businesses of borrowers are performing significantly better than those of nonborrowers on total sales revenue and business net worth. Moreover, the study concludes that microcredit is a useful tool to alleviate poverty among women through income generation resulting from their involvement in micro-enterprise activities.

Alam (2013) examines the impact of credit and non-credit aspect on self-employment profit: a comparison of micro-credit programmes and commercial lenders in rural Bangladesh. Rural credit programmes in Bangladesh help the poor by providing collateral-free loans at a low cost. In addition, they provide social development programmes such as vocational and business training through a group-based peer monitoring system. These non-credit aspects may add to the success of micro-credit programmes. It examines the effects of credit and non-credit aspects of micro-credit programmes on self-employment profits. The results show that credit effects are larger while non-credit effects are smaller for commercial loans and demonstrate the efficacy of the non-credit aspects of the micro-credit programmes in raising profits. 
Teng, Prien, Mao, and Ling (2011) assess impacts of micro-credit on household economics of Cambodia. The study reveals that the clients who are involved in micro-credit programme have found better living standards due to growth in income and asset. In addition, micro-credit has created more job opportunities and improved household education, women's status, family welfare, and variety of economic activities. It has reduced income inequality and poverty through productive use of the micro-credit.

The basic aim of MFIs is to provide both financial and non-financial services to the clients that helps: (i) to reduce poverty, (ii) to empower women or other disadvantaged population groups, (iii) to create employment, (iv) to facilitate for socioeconomic transformation of the people. The number of evidences shows that MF plays crucial role to enhance household incomes (Wright, 2000; Khandker, 2001; Chan and Ghani, 2011), productivity (Khandker, 2001), consumption (McGuire and Conroy, 2000; Rahman, 2010), women empowerment (Morduch and Haley, 2001; $\mathrm{Li}, \mathrm{Gan}$ and $\mathrm{Hu}, 2011)$, and reducing vulnerability (Zaman, 2000; Salia, and Mbwambo, 2014). The objective of this paper is to assess the loan size and its productive application in Nepalese microfinance institutions with reference to western development region of Nepal.

\section{Data and Methodology}

The study is based on primary sources of data. The primary data has been collected through structured questionnaires. The multi-stage cluster sampling method has been applied due to wide geographical area to represent the sample from each zone of the western development region of Nepal. The survey includes 500 micro-finance clients from four districts (Nawalparasi, Kaski, Parbat, and Baglung) of western development region consisting of 300 government micro-finance institutions (GMFIs) and 200 Private MFIs (PMFIs) clients who are involved in micro-finance programme since last five years. This research has been confined to the 'D class' micro-finance institutions (MFIs) located in western development region of Nepal. The data has been analysed with the help of descriptive and inferential statistics.

\section{Definition of Variables}

The outcome variables of the study are loan size and productive application. The loan size refers to the micro-credit provided by the MFIs to the clients, categorized into six groups consisting no loan; below Nepalese rupees (NRs) 25,000; 25,000 to 50,$000 ; 50,000$ to 75,$000 ; 75,000$ to 100,000 and above 100,000 . The productive application of loan refers to utilization of microcredit by the clients to generate additional earnings through micro-business and micro-enterprises. The nature of micro-business/micro-enterprises has been broadly categorized into manufacturing and production, trading and services. The manufacturing and production represents small scale manufacturing including agricultural and livestock production. Trading enterprises include buying and selling of goods such as grocery products, clothes, stationary, and so on. Finally, service business refers to hotel, restaurant, tailoring, repairing, and so on.

\section{The Status of Micro-finance in Nepal}

The concept of micro-finance existed in its traditional form in Nepal as 'dhikuti' and 'guthiyar'. The history of the cooperative dates back to 1956, when 13 cooperatives were established by the government in Chitwan 
district. The establishment of the cooperatives has been considered as the beginning foundation for micro-credit programme in Nepal. The growth and development of Nepalese micro-finance institutions have been presented in table 1 .

Table 1: Growth and Development of Nepalese Micro-finance Institutions

\begin{tabular}{|c|c|c|c|c|c|c|c|c|c|c|}
\hline \multirow[b]{2}{*}{$\begin{array}{l}\text { Types of } \\
\text { FIs }\end{array}$} & \multicolumn{10}{|c|}{ Mid-July } \\
\hline & ฮิ & ڤ̊ & ฮి & ๕ి & 를 & 귱 & $\stackrel{m}{\bar{N}}$ & ষ্ণ & 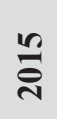 & *ै \\
\hline $\begin{array}{l}\text { MF Dev. } \\
\text { Banks }\end{array}$ & 0 & 4 & 7 & 11 & 18 & 24 & 31 & 37 & 39 & 41 \\
\hline SCCs & 0 & 6 & 19 & 20 & 15 & 16 & 15 & 15 & 15 & 15 \\
\hline FINGOs & 0 & 0 & 7 & 47 & 45 & 36 & 31 & 29 & 27 & 27 \\
\hline Total & $\mathbf{0}$ & 10 & 33 & 78 & 78 & 76 & 77 & 81 & 81 & 83 \\
\hline
\end{tabular}

Source: Banking and financial statistics, NRB, various issues.

MFDBs: Micro-finance Development Banks; SCC: Saving and Credit Cooperatives (Limited banking activities), and FINGOs: Financial Intermediary Non Government Organizations *Mid January

MFIs were formally categorized in mid-1990s and there were tremendous growth of MFIs in each year and it has been extended by 41 ' $\mathrm{D}$ ' Class MFIs (also called MF Development Banks) throughout the country till mid January 2016. Similarly, there are 15 saving and credit cooperatives (limited banking activities registered under NRB) and 27 NGO based financial intermediaries in Nepal.

\section{Results and Discussions}

\section{Savings and Loan Size}

The current loan size has been divided into six categories that have been compared with size of savings. The savings and loan size of clients has been presented in table 2 .

Table 2: Savings and Loan Size

\begin{tabular}{|c|c|c|c|c|c|c|c|}
\hline \multirow[b]{2}{*}{$\begin{array}{c}\text { Size of } \\
\text { Savings } \\
\text { (Rs.) }\end{array}$} & \multicolumn{6}{|c|}{ Current Loan Size (Rs.) } & \multirow[b]{2}{*}{ Total } \\
\hline & $\begin{array}{c}\text { No } \\
\text { Loan }\end{array}$ & 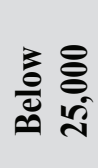 & 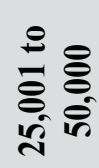 & 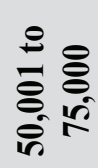 & 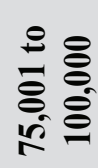 & $\begin{array}{l}08 \\
8 \\
8 \\
8 \\
8\end{array}$ & \\
\hline \multirow{2}{*}{$\begin{array}{c}\text { Below } \\
5,000\end{array}$} & 2 & 35 & 20 & 30 & 18 & 0 & 105 \\
\hline & (1.9) & (33.4) & (19.0) & (28.6) & (17.1) & $(0.0)$ & $(100.0)$ \\
\hline \multirow{2}{*}{$\begin{array}{c}5,001 \text { to } \\
10,000\end{array}$} & 13 & 19 & 124 & 63 & 50 & 3 & 272 \\
\hline & (4.7) & $(7.0)$ & (45.6) & (23.2) & (18.4) & (1.1) & $(100.0)$ \\
\hline \multirow{2}{*}{$\begin{array}{l}\text { Above } \\
10,000\end{array}$} & 1 & 4 & 27 & 41 & 49 & 1 & 123 \\
\hline & $(0.8)$ & (3.3) & (22.0) & (33.3) & (39.8) & $(0.8)$ & $(100.0)$ \\
\hline \multirow{2}{*}{ Total } & 16 & 58 & 171 & 134 & 117 & 4 & 500 \\
\hline & (3.2) & $(11.6)$ & $(34.2)$ & $(26.8)$ & (23.4) & $(0.8)$ & $(100.0)$ \\
\hline
\end{tabular}

Source: Field survey, 2014.

$=59.821$ at 10 degree of freedom and $p$-value $=$ 0.000 .

Figures in parentheses represent percentage value.

The above table shows that 96.8 percent clients have taken loans and 3.2 percent have no loans. The higher number of clients (34.2 percent) has loan size between Rs. 25,001 to Rs. 50,000 and few clients ( 0.8 percent) have loan size above Rs. 100,000. Likewise, 26.8 percent clients have loan size between Rs. 50,001 to Rs. 75,000, 23.4 percent have Rs. 75,001 to Rs. 100,000 and 11.6 percent have below Rs. 25,000.

The client whose saving size is below Rs. 5,000, large proportion of clients (33.4 percent) under this category, has taken loans below Rs. 25,000. Similarly, saving size between Rs. 5,001 to Rs. 10,000 , large number of clients (45.6 percent) has taken loans between Rs. 25,001 to Rs. 50,000. 
The clients whose saving size is above Rs. 10,000, large proportion of clients (39.8 percent) have taken loans between Rs. 75,000 to Rs. 100,000 . Since p-value of test is less than five percent level of significance, so there is association between size of savings and loans.

\section{Savings and Loan Application}

The size of savings and loan application practices adopted by the clients has been presented in table 3.

Table 3: Savings and Loans Application

\begin{tabular}{|c|c|c|c|}
\hline \multirow{2}{*}{$\begin{array}{c}\text { Size of Sav- } \\
\text { ings (Rs.) }\end{array}$} & \multicolumn{2}{|c|}{ Application of Loans } & \multirow{2}{*}{ Total } \\
\hline & Productive & Unproductive & \\
\hline \multirow{2}{*}{$\begin{array}{c}\text { Below } \\
5,000\end{array}$} & 59 & 46 & 105 \\
\hline & $(56.2)$ & $(43.8)$ & $(100.0)$ \\
\hline \multirow{2}{*}{$\begin{array}{c}5,001 \text { to } \\
10,000\end{array}$} & 162 & 110 & 272 \\
\hline & $(59.6)$ & $(40.4)$ & $(100.0)$ \\
\hline \multirow{2}{*}{$\begin{array}{l}\text { Above } \\
10,000\end{array}$} & 94 & 29 & 123 \\
\hline & $(76.4)$ & $(23.6)$ & $(100.0)$ \\
\hline \multirow{2}{*}{ Total } & 315 & 185 & 500 \\
\hline & (63.0) & $(37.0)$ & $(100.0)$ \\
\hline
\end{tabular}

Source: Field survey, 2014.

$=12.978$ at 2 degree of freedom and $p$-value $=$ 0.002 .

Figures in parentheses represent percentage value.

The above table shows that 63.0 percent clients have utilized their loans into productive sector and remaining 37.0 percent used for unproductive sector. The clients using loans in productive sector are higher as per the increment of saving size, meaning that higher the application of loans, higher the size of savings and vice-versa. The p-value of test is less than five percent, so there is association between size of savings and loan application.

MFIs should encourage savings and productive investment to the clients that helps to form capital and its proper utilization. This suggestion is relevant with the findings made by MkNelly and Christopher (1999) in Bolivia that micro-credit and education services, when provided together to groups of women, can increase income and savings.

\section{Loan Size and Nature of Business}

The loan size and nature of business has been analysed to find out the application of loan in the sector. The loan size and nature of business has been presented in table 4 .

Table 4: Loan Size and Nature of Business

\begin{tabular}{|c|c|c|c|c|}
\hline \multirow[b]{2}{*}{$\begin{array}{l}\text { Current } \\
\text { Loan Size } \\
\text { (Rs.) }\end{array}$} & \multicolumn{3}{|c|}{ Nature of Business } & \multirow[b]{2}{*}{ Total } \\
\hline & $\begin{array}{l}\text { Manufac- } \\
\text { turing and } \\
\text { Production }\end{array}$ & 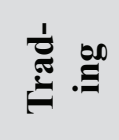 & $\dot{d}$ & \\
\hline No loan & $\begin{array}{c}1 \\
(16.7)\end{array}$ & $\begin{array}{c}1 \\
(16.7)\end{array}$ & $\begin{array}{c}4 \\
(66.6)\end{array}$ & $\begin{array}{c}6 \\
(100.0)\end{array}$ \\
\hline $\begin{array}{l}\text { Below } \\
25,000\end{array}$ & $\begin{array}{c}3 \\
(23.1)\end{array}$ & $\begin{array}{c}6 \\
(46.2)\end{array}$ & $\begin{array}{c}4 \\
(30.7)\end{array}$ & $\begin{array}{c}13 \\
(100.0)\end{array}$ \\
\hline $\begin{array}{c}25,001- \\
50,000\end{array}$ & $\begin{array}{c}13 \\
(13.8)\end{array}$ & $\begin{array}{c}37 \\
(39.4)\end{array}$ & $\begin{array}{c}44 \\
(46.8)\end{array}$ & $\begin{array}{c}94 \\
1.000\end{array}$ \\
\hline $\begin{array}{c}50,001- \\
75,000\end{array}$ & $\begin{array}{c}15 \\
(15.0)\end{array}$ & $\begin{array}{c}44 \\
(44.0)\end{array}$ & $\begin{array}{c}41 \\
(41.0)\end{array}$ & $\begin{array}{c}100 \\
(100.0)\end{array}$ \\
\hline $\begin{array}{l}75001- \\
100,000\end{array}$ & $\begin{array}{c}8 \\
(8.2)\end{array}$ & $\begin{array}{c}45 \\
(45.9)\end{array}$ & $\begin{array}{c}45 \\
(45.9)\end{array}$ & $\begin{array}{c}98 \\
1.000\end{array}$ \\
\hline $\begin{array}{c}\text { Above } \\
100,000\end{array}$ & $\begin{array}{c}1 \\
(25.0)\end{array}$ & $\begin{array}{c}2 \\
(50.0)\end{array}$ & $\begin{array}{c}1 \\
(25.0)\end{array}$ & $\begin{array}{c}4 \\
(100.0)\end{array}$ \\
\hline Total & $\begin{array}{c}41 \\
(13.0)\end{array}$ & $\begin{array}{c}135 \\
(42.9)\end{array}$ & $\begin{array}{c}139 \\
(44.1)\end{array}$ & $\begin{array}{c}315 \\
(100.0)\end{array}$ \\
\hline
\end{tabular}

Source: Field survey, 2014.

$=7.185$ at 10 degree of freedom and $p$-value $=$ 0.708 .

Figures in parentheses represent percentage value.

The above table shows that 44.1 percent clients have applied their loans into the service sectors, closely followed by trading sectors (42.9 percent), and manufacturing and production (13.0 percent). It means that application of loans in service sector 
is high and low for manufacturing and production. Few clients (1.2 percent) have no loans but still involved in productive investment. It refers that they may have become self-dependent from their business earnings and not using loans right now. Since p-value of test is greater than five percent level of significance, so there is no association between current loan size and nature of business.

\section{Loan Size and Ethnicity}

The loan size and ethnicity shows the number of loan taking clients in terms of ethnicity. The current loan size and ethnicity has been presented in table 5 .

\begin{tabular}{|c|c|c|c|c|c|}
\hline \multirow{2}{*}{$\begin{array}{c}\text { Current } \\
\text { Loan Size } \\
\text { (Rs.) }\end{array}$} & \multicolumn{4}{|c|}{ Ethnic Groups } & \multirow{2}{*}{ Total } \\
\hline & Dalit & Janajati & Adhibasi & BCO* & \\
\hline No loan & $\begin{array}{c}4 \\
(25.0)\end{array}$ & $\begin{array}{c}6 \\
(37.5)\end{array}$ & $\begin{array}{c}0 \\
(0.0)\end{array}$ & $\begin{array}{c}6 \\
(37.5)\end{array}$ & $\begin{array}{c}16 \\
(100.0)\end{array}$ \\
\hline $\begin{array}{l}\text { Below } \\
25,000\end{array}$ & $\begin{array}{c}23 \\
(53.5)\end{array}$ & $\begin{array}{c}8 \\
(18.6)\end{array}$ & $\begin{array}{c}7 \\
(16.3)\end{array}$ & $\begin{array}{c}5 \\
(11.6)\end{array}$ & $\begin{array}{c}43 \\
(100.0)\end{array}$ \\
\hline $\begin{array}{c}25,001- \\
50,000\end{array}$ & $\begin{array}{c}64 \\
(34.4)\end{array}$ & $\begin{array}{c}71 \\
(38.2)\end{array}$ & $\begin{array}{c}18 \\
(9.7)\end{array}$ & $\begin{array}{c}33 \\
(17.7)\end{array}$ & $\begin{array}{c}186 \\
(100.0)\end{array}$ \\
\hline $\begin{array}{c}50,001- \\
75,000\end{array}$ & $\begin{array}{c}21 \\
(15.7)\end{array}$ & $\begin{array}{c}63 \\
(47.0)\end{array}$ & $\begin{array}{c}4 \\
(3.0)\end{array}$ & $\begin{array}{c}46 \\
(34.3)\end{array}$ & $\begin{array}{c}134 \\
(100.0)\end{array}$ \\
\hline $\begin{array}{l}75001- \\
100,000\end{array}$ & $\begin{array}{c}25 \\
(21.4)\end{array}$ & $\begin{array}{c}29 \\
(24.8)\end{array}$ & $\begin{array}{c}8 \\
(6.8)\end{array}$ & $\begin{array}{c}55 \\
(47.0)\end{array}$ & $\begin{array}{c}117 \\
(100.0)\end{array}$ \\
\hline $\begin{array}{l}\text { Above } \\
100,000\end{array}$ & $\begin{array}{c}0 \\
(0.0)\end{array}$ & $\begin{array}{c}1 \\
(25.0)\end{array}$ & $\begin{array}{c}0 \\
(0.0)\end{array}$ & $\begin{array}{c}3 \\
(75.0)\end{array}$ & $\begin{array}{c}4 \\
(100.0)\end{array}$ \\
\hline Total & $\begin{array}{c}137 \\
(27.4)\end{array}$ & $\begin{array}{c}178 \\
(35.6)\end{array}$ & $\begin{array}{c}37 \\
(7.4)\end{array}$ & $\begin{array}{c}148 \\
(29.6)\end{array}$ & $\begin{array}{c}500 \\
(100.0)\end{array}$ \\
\hline
\end{tabular}

Source: Field survey, 2014.

$=76.457$ at 15 degree of freedom and $p$-value $=$ 0.000 .

*BCO refers to Brahaman, Chhetri, and Others.

Figures in parentheses represent percentage value.
Since p-value of test is less than five percent level of significance, so there is association between current loan size and ethnicity. The study shows that clients who are taking loans below Rs. 25,000 , involvement of Dalit people are more (53.5 percent) than other ethnicity. Likewise, loan size between Rs. 25,001 to Rs. 50,000 and Rs. 50,001 to Rs. 75,000, participation of Janajati people is more and loan size above Rs. 75,000, participation of BCO is more. Majority of Dalit (63.5 percent) are taking loans below Rs. 50,000 consisting 16.8 percent taking below Rs. 25,000 and 46.7 percent taking between Rs. 25,001 to Rs. 50,000 .

\section{Loan Size and Duration of Membership}

The loan size and duration of membership is assessed to explore the effect of loan size in terms of duration of membership. The current loan size and duration of membership has been presented in table 6.

Table 6: Loan Size and Duration of Membership

\begin{tabular}{|c|c|c|c|c|}
\hline \multirow{2}{*}{$\begin{array}{c}\text { Current } \\
\text { Loan Size } \\
\text { (Rs.) }\end{array}$} & \multicolumn{3}{|c|}{ Duration of Membership (Years) } & \multirow{2}{*}{ Total } \\
\hline & 5 to 8 & 9 to 12 & Above 12 & \\
\hline No loan & $\begin{array}{c}13 \\
(81.3)\end{array}$ & $\begin{array}{c}1 \\
(6.3)\end{array}$ & $\begin{array}{c}2 \\
(12.5)\end{array}$ & $\begin{array}{c}16 \\
(100.0)\end{array}$ \\
\hline $\begin{array}{l}\text { Below } \\
25,000\end{array}$ & $\begin{array}{c}34 \\
(79.1)\end{array}$ & $\begin{array}{c}6 \\
(14.0)\end{array}$ & $\begin{array}{c}3 \\
(7.0)\end{array}$ & $\begin{array}{c}43 \\
(100.0)\end{array}$ \\
\hline $\begin{array}{c}25,001- \\
50,000\end{array}$ & $\begin{array}{c}124 \\
(66.7)\end{array}$ & $\begin{array}{c}27 \\
(14.5)\end{array}$ & $\begin{array}{c}35 \\
(18.8)\end{array}$ & $\begin{array}{c}186 \\
(100.0)\end{array}$ \\
\hline $\begin{array}{c}50,001- \\
75,000\end{array}$ & $\begin{array}{c}82 \\
(61.2)\end{array}$ & $\begin{array}{c}26 \\
(19.4)\end{array}$ & $\begin{array}{c}26 \\
(19.4)\end{array}$ & $\begin{array}{c}134 \\
(100.0)\end{array}$ \\
\hline $\begin{array}{l}75001- \\
100,000\end{array}$ & $\begin{array}{c}32 \\
(27.3)\end{array}$ & $\begin{array}{c}30 \\
(25.6)\end{array}$ & $\begin{array}{c}55 \\
(47.1)\end{array}$ & $\begin{array}{c}117 \\
(100.0)\end{array}$ \\
\hline $\begin{array}{c}\text { Above } \\
100,000\end{array}$ & $\begin{array}{c}1 \\
(25.0)\end{array}$ & $\begin{array}{c}1 \\
(25.0)\end{array}$ & $\begin{array}{c}2 \\
(50.0)\end{array}$ & $\begin{array}{c}4 \\
(100.0)\end{array}$ \\
\hline Total & $\begin{array}{c}286 \\
(57.2)\end{array}$ & $\begin{array}{c}91 \\
(18.2)\end{array}$ & $\begin{array}{c}123 \\
(24.6)\end{array}$ & $\begin{array}{c}500 \\
(100.0)\end{array}$ \\
\hline
\end{tabular}

Source: Field survey, 2014. 
$=71.460$ at 10 degree of freedom and $p$-value $=$ 0.000 .

Figures in parentheses represent percentage value.

The above table shows that majority of clients ( 57.2 percent) have 5 to 8 years duration of membership, 18.2 percent have 9 to 12 years, and 24.6 percent have more than 12 years duration of membership in MFIs. Majority of clients (55.2 percent) having 5 to 8 years duration of membership have taken loans below Rs. 50,000, consisting 11.8 percent below Rs. 25,000 and 43.4 percent between Rs. 25,001 to Rs. 50,000. Similarly, most of the clients (91.2 percent) having 9 to 12 years duration of membership have taken loans between Rs. 25,001 to Rs. 100,000 , consisting 29.6 percent between Rs. 25,001 to Rs. 50,000, 28.6 percent between Rs. 50,001 to Rs. 75,000, and 33.0 percent between Rs. 75,001 to Rs. 100,000. The clients whose membership are above 12 years, majority (65.8 percent) have loan size between Rs. 50,001 to Rs. 100,000, consisting 21.1 percent have between Rs. 50,001 to Rs. 75,000 and 44.7 percent have between Rs. 75,001 to Rs. 100,000.

Since p-value of test is less than five percent level of significance, so there is association between loan size and duration of membership. The study shows that clients whose membership is relatively higher, they have greater amount of loan sizes and vice-versa.

\section{Size of Loans and Its Application}

The loan size and its application have been compared to find out the proper utilization of loans by the clients. The size of loans and its application have been presented in table 7 .
Table 7: Size of Loans and Its Application

\begin{tabular}{|c|c|c|c|}
\hline \multirow{2}{*}{$\begin{array}{c}\text { Size of } \\
\text { Current } \\
\text { Loan (Rs.) }\end{array}$} & \multicolumn{2}{|c|}{ Application of Loans } & \multirow{2}{*}{ Total } \\
\hline & Productive & Unproductive & \\
\hline No loan & $\begin{array}{c}6 \\
(37.5)\end{array}$ & $\begin{array}{c}10 \\
(62.5)\end{array}$ & $\begin{array}{c}16 \\
(100.0)\end{array}$ \\
\hline $\begin{array}{l}\text { Below } \\
25,000\end{array}$ & $\begin{array}{c}13 \\
(30.2)\end{array}$ & $\begin{array}{c}30 \\
(69.8)\end{array}$ & $\begin{array}{c}43 \\
(100.0)\end{array}$ \\
\hline $\begin{array}{c}25,001- \\
50,000\end{array}$ & $\begin{array}{c}94 \\
(50.5)\end{array}$ & $\begin{array}{c}92 \\
(49.5)\end{array}$ & $\begin{array}{c}186 \\
(100.0)\end{array}$ \\
\hline $\begin{array}{c}50,001- \\
75,000\end{array}$ & $\begin{array}{c}100 \\
(74.6)\end{array}$ & $\begin{array}{c}34 \\
(25.4)\end{array}$ & $\begin{array}{c}134 \\
(100.0)\end{array}$ \\
\hline $\begin{array}{l}75001- \\
100,000\end{array}$ & $\begin{array}{c}98 \\
(83.8)\end{array}$ & $\begin{array}{c}19 \\
(16.2)\end{array}$ & $\begin{array}{c}117 \\
(100.0)\end{array}$ \\
\hline $\begin{array}{l}\text { Above } \\
100,000\end{array}$ & $\begin{array}{c}4 \\
(100.0)\end{array}$ & $\begin{array}{c}0 \\
(0.0)\end{array}$ & $\begin{array}{c}4 \\
(100.0)\end{array}$ \\
\hline Total & $\begin{array}{c}315 \\
(63.0)\end{array}$ & $\begin{array}{c}185 \\
(37.0)\end{array}$ & $\begin{array}{c}500 \\
(100.0)\end{array}$ \\
\hline
\end{tabular}

Source: Field survey, 2014.

$=68.417$ at 5 degree of freedom and p-value $=$ 0.000 .

Figures in parentheses represent percentage value.

As per the monitory policy $2015 / 16$, the maximum loan size is Rs. 300,000 for collateral free loans and Rs. 700,000 for collateral based loans. Most of the clients (87.4 percent) have taken loans between Rs. 25,000 to Rs. 100,000, out of which 37.2 percent have loan size of Rs. 25,001 to 
Rs. 50,000, 26.8 percent have Rs. 50,001 to Rs. 75,000, and 23.4 percent have Rs. 75,001 to Rs. 100,000 .

It is obvious from the above table that those clients whose size of loans are less than Rs. 25,000, there is poor application (69.8 percent) of loans in productive sector. The loan size between Rs. 25,001 to Rs. 50,000 has only 50.0 percent application of loans in productive sector. But loan size having greater than Rs. 50,000 has higher degree of loan application in the productive sector. The clients having loan size of Rs. 50,001 to Rs. 75,000 has 74.6 percent application of loan in productive sector. Similarly, loan size between Rs. 75,001 to Rs. 100,000 has 83.8 percent application, and loan size having more than Rs. 100,000 has cent percent application in productive sector.

The study shows that who have taken loans below Rs. 25,000, mostly spent on household and domestic use, and found poor initiation of microbusiness. Since p-value of test is less than five percent significance level, so there is positive association between loan size and its application. It refers that higher the loan size, higher the application of loans in productive sector and viceversa. So, MFIs should provide optimum size of loans to the clients as per the provision of monitory policy to increase its productive application however, strict monitoring and supervision is essential.

\section{Status of Micro-business and Employment}

The status of micro-business and employment explores number of micro-business creation, number of employees per business, total employment, and employment generation in terms of ethnicity. The status of micro-business and employment has been presented in table 8 .
Table 8: Status of Micro-business and Employment

\begin{tabular}{|c|c|c|c|c|c|c|}
\hline \multirow{2}{*}{ 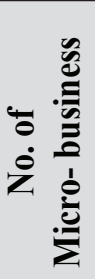 } & \multirow{2}{*}{ 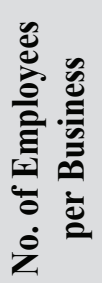 } & \multirow[b]{2}{*}{ } & \multicolumn{4}{|c|}{ Employment and Ethnicity } \\
\hline & & & Dalit & 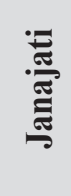 & 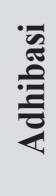 & BCO* \\
\hline 111 & 1 & 111 & 22 & 34 & 13 & 42 \\
\hline 136 & 2 & 272 & 47 & 113 & 24 & 88 \\
\hline 33 & 3 & 99 & 28 & 21 & 15 & 35 \\
\hline 23 & 4 & 92 & 18 & 50 & 8 & 16 \\
\hline 5 & 5 & 25 & 15 & 10 & 0 & 0 \\
\hline 2 & 6 & 12 & 2 & 2 & 0 & 8 \\
\hline 1 & 7 & 7 & 0 & 5 & 2 & 0 \\
\hline 3 & 8 & 24 & 4 & 11 & 8 & 1 \\
\hline 1 & 12 & 12 & 2 & 10 & 0 & 0 \\
\hline 315 & Total & 654 & 138 & 256 & 70 & 190 \\
\hline
\end{tabular}

Source: Field survey, 2014.

* BCO refers to Brahaman, Chhetri, and Others.

Note: Average employment per business $=$ $654 / 315=2.1$.

The study shows that 315 micro-business and enterprises have been created by clients that represent 63.0 percent clients' involvement in enterprise creation. The average employment rate per business is 2.1, out of which Janajati (0.81) has higher employment rate per business and Adhibasi (0.22) has lower. Similarly, employment rate per business for Dalit is 0.44 , and for $\mathrm{BCO}$ (Brahaman, Cheetri, and others) is 0.60. It can be observed from the above table that large number of micro-business (27.2 percent) has provided employment opportunities for two people per micro-business. In addition to this, 111 microbusinesses operated by the clients have provided employment to the single person per microbusiness whereas a single micro-business (related to manufacturing) has provided employment to 12 persons. It may be concluded that MF facilitates to generate self-employment and employment opportunities through micro-credit services. 


\section{Conclusion and Suggestions}

The study shows that there is positive association among size of savings and loans, size of savings and loan application, current loan size and ethnicity, loan size and duration of membership, and finally loan size and its application. It has been found that 44.1 percent clients have applied their loans into the service sectors, 42.9 percent by trading sectors, and 13.0 percent by manufacturing and production sectors respectively. The application of loans in service sector is relatively higher as compared to other sectors. It can be concluded that clients who have taken small size of loans, they have mostly spent their loans on domestic purposes and found poor application of loans in

\section{REFERENCES}

Alam, S. (2013). The impact of credit and non-credit aspect on self-employment profit: A comparison of micro-credit programmes and commercial lenders in rural Bangladesh. The Journal of Developing Areas, 47 (1): 23-45.

Chan, S. H., \& Ghani, M. A. (2011). The impact of micro-loans in vulnerable remote areas: Evidence from Malaysia. Asia Pacific Business Review, 17(1): 45-66.

Khandker, S. (2001). Does micro-finance really benefit the poor? Evidence from Bangladesh. Paper delivered at Asia and Pacific forum on poverty: Reforming policies and institutions for poverty reduction held by the Asian Development Bank, Manila, February 5-9. Available from: http:// www.adb.org/poverty/forum/ pdf/Khan dker. pdf.

Li, X., Gan, C., \& Hu, B. (2011). The Impact of microcredit on women's empowerment: Evidence from China. Journal of Chinese Economic and Business Studies, 9 (3): 239-261. micro-business whereas big loan size clients have greater application of loans in productive sectors. The study shows that MF intervention facilitates to generate self-employment and employment opportunities through micro-credit services. Micro-finance institutions should increase loan size (as per the provision of monitory policy) with necessary entrepreneurship skills that will help to enhance productive application of loans however, strict monitoring and supervision is essential. Thus, MFIs should give equal priority for nonfinancial services such as financial literacy and provision of entrepreneurship skills through government and non-government organizations that ultimately helps to utilize micro-credit into productive sectors.

Matthaus-Maier, I., \& Von Pischke, J. D. (2009). New partnerships for innovation in micro-finance. Germany: Springer-Kfw, 1-379.

McGuire, P. B., \& Conroy, J. D. (2000). The Microfinance phenomenon. Asia Pacific Review, 7(1): 90-108.

MkNelly B., \& Christopher, D. (1999). Impact of credit with education on mothers and their young children's nutrition: CRECER credit with education program in Bolivia. Freedom from Hunger, Research Paper No. 5.

Mokhtar, S. H. (2011). Micro-finance performance in Malaysia. Ph.D. Dissertation, Lincoln

Morduch, J., \& Haley, B. (2002). Analysis of the effects of micro-finance on poverty reduction. Canadian International Development Agency. NYUWagner Working PaperNo. 1014. Retrieved from: http://www.microfinancegateway.org/ $\mathrm{gm} /$ docu ment 1.9.29382/analysis $\% 20$ of $\% 20$ the $\% 20$ effects.pdf. 
Nepal Rastra Bank. Banking and financial statistics. Various Issues. Nepal Rastra Bank, Kathmandu, Nepal.

Nepal Rastra Bank (2015). Monitory policy for 2015/16. Nepal Rastra Bank, Kathmandu, Nepal.

Rahaman, S. (2010). Consumption difference between micro-credit borrowers and non-borrowers: A Bangladesh experience. The Journal of Developing Areas, 43(2): 313-326.

Salia, P. J., \& Mbwambo, J. S. (2014). Does microcredit make any difference on borrowers' businesses? Evidences from a survey of women owned micro-enterprises in Tanzania. International Journal of Social Sciences and
Entrepreneurship, 1 (9): 431-444.

Teng, S., Prien, S., Mao, N., \& Ling, B. (2011). Impacts of micro-credit on household economics. International Journal of Environmental and Rural Development, 2(1): 108-114.

Wright, G.A.N. (2000). Micro-finance systems: Designing quality financial services for the poor. London: Zed Books.

Zaman, H. (2000). Assessing the poverty and vulnerability impact of micro-credit in Bangladesh: A case study of BRAC. World Bank. Retrieved from www.worldban k. org /html/dec/Publications/Workpapers/ wps2000series/wps2145/wps2145.pdf.

and international conferences. He was awarded a Ph.D. degree in 2015 from Banaras Hindu University (BHU), India. His area of interests includes micro finance and financial inclusion.

e-mail:dhunganabharat.pu@gmail.com various reputed national and international journals. He also presented more than 10 papers in national
Finance at School of Business, Pokhara University, Nepal. He has been involved in teaching for a decade and published over a dozen research papers in 